\title{
Modeling dynamics of price changes in housing market in Kazan
}

\author{
Khabibrakhmanova R.R. \\ Department of State and Municipal Management \\ Kazan (Volga region) Federal University \\ Kazan, Russian Federation \\ rezedarinatovna@gmail.com
}

\author{
Abramov R.A. \\ Department of State and Municipal Management \\ Plekhanov Russian University of Economics \\ Moscow, Russian Federation \\ oef08@mail.ru
}

\begin{abstract}
The article provides mathematical models to forecast the dynamics of price changing of residential property in Kazan. Verification of models was performed and results of the comparative analysis of prices in the secondary market of residential property in Kazan and other major cities of the Volga federal district were obtained. In this article, authors research the possibility of modelling (including with using the Fischer-Pry model) in forecasting the dynamics of prices in the primary and the secondary market of housing of Kazan, upon the influence of the external factors on the dynamics of prices of residential property. The issues of the system analysis of the real estate market, the methodology of investment analysis, as well as statistical monitoring and modeling of the real estate market, are being studied. The paper examines the factors that have a significant impact on the demand for housing and consequently on the dynamics of price changes.
\end{abstract}

Keywords-mathematical modelling, prices, price dynamics, residential property market, primary market of residential property, secondary market of residential property, forecasting.

\section{INTRODUCTION}

The residential issue in Russia had always been and remains vital for citizens who have to deal with it all through their life. This issue is equally important for bodies of state and municipal power that should create conditions for execution of the constitutional right of citizens for housing. The possibility to obtain housing by citizens of Russia is influenced by a number of factors, such as prices for residential property, terms of mortgage, availability and accessibility of efficient forms of state support in purchase of a property, and other.

In this article, authors research the possibility of modelling (including with using the Fischer-Pry model) in forecasting the dynamics of prices in the primary and the secondary market of housing of Kazan, upon the influence of the external factors on the dynamics of prices of residential property.

\section{CURRENT SITUATION}

The real estate market of Kazan had been currently developing in last years. This is stipulated by a series of events, among which it is possible to mention the celebration of the millennial jubilee of Kazan city, as well as preparation and holding a number of major sport events, including the Universiade (2013), the European Championship on Badminton (2014), the World Championship on Fencing (2014), the World Championship on Water Sports (2015), games of Football Confederation Cups (2017), and the World Football Championship (2018). Preparation to such events requires significant investments in development and maintenance of the entire urban infrastructure at a high level. As result, the investment attractiveness of a city increases together with life quality of the population.

Moreover, prices of real estate can be influenced by programs for support of citizens in purchase and construction of property in Kazan. Currently, improvement of housing situation of citizens of Kazan is made within the scope of realization of state and municipal programs [1]. Under the Federal Target Program "Housing", three sub-programs are being realized. The first one suggests issue of state housing certificates for purchase of residential property among liquidators of the consequences of radiation accidents and disasters, as well as among forced migrants. The second subprogram suggests provision of subsidies for purchase of property at the account of subventions granted from the Federal Fund of Compensations to categories of citizens who are registered for improvement of housing situation (participants of the Great Patriotic War, participants of military actions, disabled people and families with disabled children, etc.). The third sub-program "Provision of housing to young families" suggests provision of a social payment for purchase (construction) of residential property in amount of $35 \%$ of the average price - for young families that have no children; $40 \%$ of the average price - for young families that have one or more children.

Starting from 2005, in the territory of Kazan the regional program "Provision of housing to citizens in the Republic of Tatarstan under social mortgage" is being realized.

With the purpose of improvement of housing situation among citizens of Kazan, the municipal program "Housing for citizens for 2007-2027" [2] was developed, which comprises sub-programs "social accommodation" and "affordable accommodation". The first sub-program suggests provision of free accommodation under social rent agreements to citizens who were recognized as economically disadvantaged. The sub- 
program "Affordable housing" is a municipal analogue of the program "Social mortgage".

Beside the abovementioned programs, in Kazan is also being realized the Decree of the RT Cabinet of Ministers "On measures for provision of housing to families with many children that need improvement of accommodation, orphans and children who were left without parental care, who do not have residential property registered at them".

All these factors greatly influence the residential demand and the price dynamics, respectively.

\section{LITERATURE SURVEY}

The rapid increase of the housing prices, the high index of correlation of the housing price and the income in big cities always cause the dispute and attract many scientists. Therefore, it is of no surprise that there are a great number of authors concentrated on the analyses of the housing market problems. The various indexes and counting models are used in prognosis of the future housing prices, and the development of the certain housing policy $[3,4]$

There are the scientists who are interested in the housing price formation process directly. They research the assets, and the correlation of the rent and housing prices [5].

The questions of analyses of the housing prices are researched in the article of Y. Li. He reveals the dependence of the housing prices changes from the changes of the income of the population and from the changes in the level of governmental assistance, using the correlation analyses. The analysis of the housing prices is made in dynamics in the period of 30 years in 26 districts of the State California [6].

Some authors like W. Cai and X. Lu insist that there must be systematic approach in analyses of the housing availability problems and in accomplishing the strategy of the competent housing policy. The dynamic of the housing prices increase should be taken in the consideration as well as the correlation of the factors which define the housing availability in correlation with the income of the citizens and mention the correlation of the housing availability and its quality. These aspects are very important for the improvement of effectiveness of the housing policy [7].

During the analysis of the consumers preferences and satisfaction with the housing conditions Wang, M.a, Bao, Ha Lin, P.T. arrived at unpredicted results in their article. They researched the influence of the mega-event, the preparation and holding the Olympic games of 2008 in Beijing to be more exact, on the housing market. They used the consumer preferences of the citizens in their research. As a result, they came to the negative conclusion: besides the rapid process of the city's housing infrastructure improvement, socially unsecured groups of citizens turned out to be in disadvantageous position in the process of resettlement. Their negative expectations came true. The authors think that such problems should not be concealed. On the contrary, the attention of people and government must be drawn to this problem [8]. As a possible answer to this question the article of $\mathrm{Ng}, \mathrm{K} . \mathrm{F}$., Lo, H.K. says that there is a relation between the spatial distribution of the housing, consumers' preferences and the profitability of building for the developers. At that, they offer to use different rules of land tenure in order of concordance of the opposite interests [9].

The questions of the system analyses of the realty market, methodology of the investment analyses, statistical monitoring and modeling of the realty market in Russia are considered in the articles of G.M. Sternik and S.G. Sternik [10].

\section{METHODOLOGY OF THE RESEARCH}

According to Sternik G.M., all the variety of the methods used to forecast the development of the real estate market can formally be divided into two groups subject to the applied approaches: heuristic (logical-analytical), or fundamental analysis, and mathematical, or technical analysis. At that, the author reasonably states that the most efficient methods and methods that have optimal forecasting ability are combined methods, which include elements of both these approaches [11].

Of the models used to forecast the price dynamics of the real estate market is the Fischer-Pry model [12, 13, 14, 15] that belongs to the category of logical curves, general profile of which can be presented by the following equation (1):

$$
Y(t)=\frac{k}{1+e^{f(t)}},
$$

where $\mathrm{f}(\mathrm{t})$ is a function having the following profile (2):

$$
f(t)=-a-b \cdot t(d ; g),
$$

while $t(d ; g)$ can take different forms, which may affect the transformation of the initial linear-logistical curve into other types of models.

This type of model was used by G.M.Sternik to forecast the dynamics of development of the real estate market in a number of Russian cities at the early stages of establishment of the real estate market [10]. The author marks the important feature of this model: while in the short-term and the middle-term period it demonstrates the high forecasting ability, in the long-term perspective after transfer of the system to the new state the model can quite precisely describe the stabilization, but does not forecast further dynamics of trends [11].

To study the real estate price dynamics in Kazan, we used logistic functions that quite accurately approximate the actual time series and simulate further development of processes within the scope of one cycle.

\section{EMPIRIC STUDIES: KEY RESULTS}

In the context of Kazan, we had developed logistic models to forecast the price dynamics in the primary and the secondary real estate markets in the post-crisis period of economy development (2010-2014). The obtained models appear as follows:

$$
Y_{1}=\frac{53.0376}{1+e^{4.2289-0.1698 \cdot t}},
$$




$$
Y_{2}=\frac{72.1736}{1+e^{3.8713-0.1539 \cdot t}},
$$

where $\mathrm{Y}_{1}$ is the average monthly price of an offer in the primary real estate market in Kazan, thous. rub. / sq. m, $\mathrm{Y}_{2}$ is the average monthly price of an offer in the secondary real estate market in Kazan, thous. rub. / sq. m.

The critical stage of mathematical modelling is verification of the obtained equations. While the authors developed models $(3,4)$ in 2012 , with a forecasting period up to the end of 2014 , accuracy of forecasting can be predicted by comparing with actual data for the period from August 2012 till December 2014 (Fig. 1). The results of the made verification of the model (3) are given in Table 1.

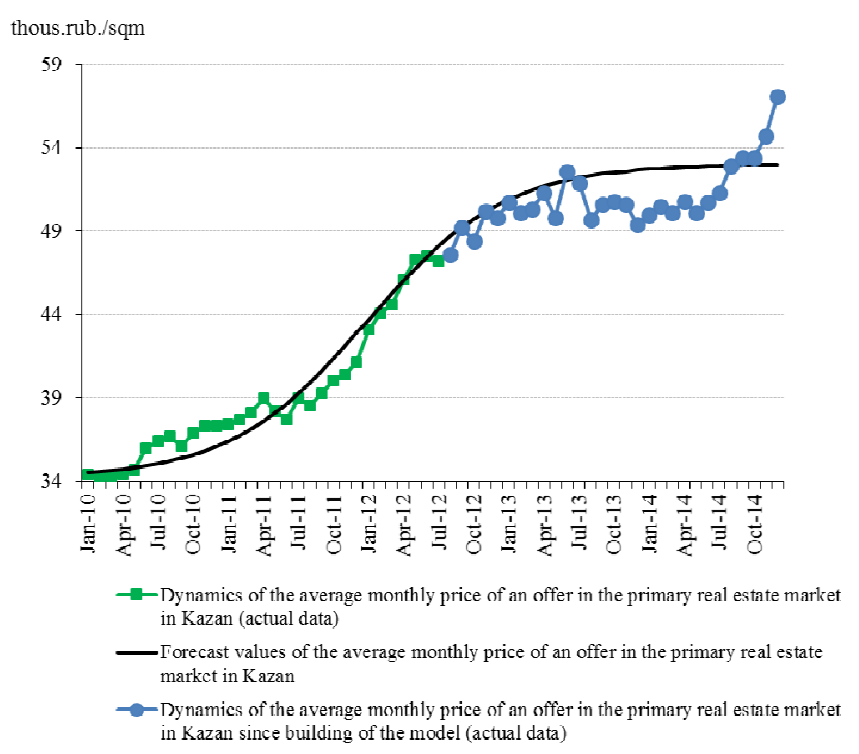

Fig. 1. Simulation of the price dynamics in the primary real estate market in Kazan based on the built logistic model (3)

TABLE I. ESTIMATE OF THE AVERAGE MONTHLY PRICES IN THE PRIMARY REAL ESTATE MARKET IN KAZAN UNDER THE EQUATION (3) AND DEVIATIONS FROM THE ACTUAL VALUES OF THE AVERAGE MONTHLY OFFER PRICES

\begin{tabular}{|c|c|c|c|c|}
\hline Month & $\begin{array}{c}\text { Average } \\
\text { monthly unit } \\
\text { price in the } \\
\text { primary real } \\
\text { estate market } \\
\text { in Kazan, } \\
\text { thous.rub/sq } \\
\text { m. (actual } \\
\text { values) }\end{array}$ & $\begin{array}{c}\text { Average } \\
\text { monthly unit } \\
\text { price in the } \\
\text { primary real } \\
\text { estate market } \\
\text { in Kazan, } \\
\text { thous.rub/sq } \\
\text { m. } \\
\text { (estimated } \\
\text { values) }\end{array}$ & $\begin{array}{c}\text { Deviatio } \\
\text { ns, } \\
\text { absolute } \\
\text { values, } \\
\text { thous.ru } \\
\text { b. }\end{array}$ & $\begin{array}{c}\text { Deviations } \\
\% \text { of } \\
\text { actual } \\
\text { value }\end{array}$ \\
\hline Aug.12 & 47.6 & 48.7 & 1.1 & 2.3 \\
\hline Sep.12 & 49.2 & 49.2 & 0.0 & 0.1 \\
\hline Oct.12 & 48.4 & 49.7 & 1.3 & 2.7 \\
\hline Nov.12 & 50.2 & 50.2 & 0.0 & 0.1 \\
\hline Dec.12 & 49.8 & 50.6 & 0.8 & 1.5 \\
\hline Jan.13 & 50.7 & 50.9 & 0.2 & 0.4 \\
\hline Feb.13 & 50.1 & 51.2 & 1.1 & 2.2 \\
\hline Mar.13 & 50.3 & 51.5 & 1.2 & 2.3 \\
\hline Apr.13 & 51.3 & 51.7 & 0.4 & 0.8 \\
\hline
\end{tabular}

\begin{tabular}{|c|c|c|c|c|}
\hline May.13 & 49.8 & 51.9 & 2.1 & 4.2 \\
\hline Jun. 13 & 52.6 & 52.1 & 0.5 & 1.0 \\
\hline Jul.13 & 51.9 & 52.2 & 0.3 & 0.6 \\
\hline Aug.13 & 49.7 & 52.3 & 2.6 & 5.3 \\
\hline Sep.13 & 50.6 & 52.4 & 1.8 & 3.6 \\
\hline Oct.13 & 50.8 & 52.5 & 1.7 & 3.4 \\
\hline Nov.13 & 50.6 & 52.6 & 2.0 & 4.0 \\
\hline Dec.13 & 49.4 & 52.7 & 3.3 & 6.6 \\
\hline Jan.14 & 50 & 52.7 & 2.7 & 5.5 \\
\hline Feb.14 & 50.5 & 52.8 & 2.3 & 4.5 \\
\hline Mar.14 & 50.1 & 52.8 & 2.7 & 5.4 \\
\hline Apr.14 & 50.8 & 52.9 & 2.1 & 4.0 \\
\hline May .14 & 50.1 & 52.9 & 2.8 & 5.5 \\
\hline Jun.14 & 50.7 & 52.9 & 2.2 & 4.3 \\
\hline Jul.14 & 51.3 & 52.9 & 1.6 & 3.2 \\
\hline Aug.14 & 52.9 & 52.9 & 0.0 & 0.1 \\
\hline Sep.14 & 53.4 & 53.0 & 0.4 & 0.8 \\
\hline Oct. 14 & 53.4 & 53.0 & 0.4 & 0.8 \\
\hline Nov.14 & 54.7 & 53.0 & 1.7 & 3.1 \\
\hline Dec.14 & 57.1 & 53.0 & 4.1 & 7.2 \\
\hline \multicolumn{3}{|c|}{ Average deviation index: } & 1.16 & 2.55 \\
\hline \multicolumn{3}{|c|}{ Maximum deviation: } & 4.11 & 7.20 \\
\hline \multicolumn{3}{|c|}{ Minimum deviation: } & 0.03 & 0.06 \\
\hline
\end{tabular}

The verification results of the model (3) confirm its high accuracy of forecasting for the period up to the end of 2014. The relative value of the average deviation of estimated values from actual values made $2.55 \%$, while minimum deviation made $0.06 \%$ (in September of 2012), and maximum deviation $7.2 \%$ (in December of 2014). The average deviation in absolute expression made 1.16 thous. rub/sq. m., minimum value 0.03 thous. rub/sq. m., and maximum value of the absolute deviation 4.11 thous. rub/sq. m.

By analyzing the actual data on the price dynamics of the secondary real estate market in Kazan, the authors concluded that transfer to price stabilization in this market in 2013-14 occurred asymptotically, gradually approaching the forecasting values of the logistic model (4), as it can be seen in Fig. 2.

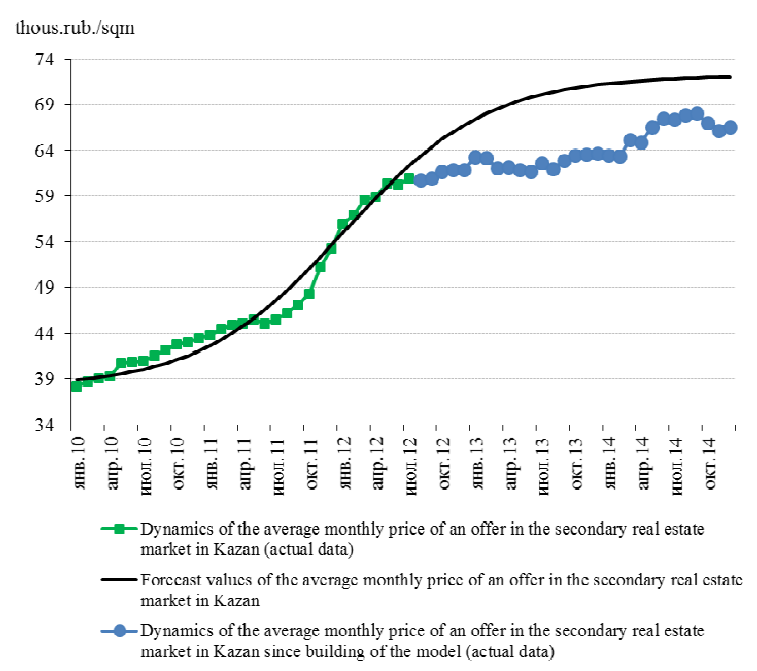

Fig. 2. Simulation of the price dynamics in the secondary real estate market in Kazan based on the built logistic model (4) 
The average relative deviation of the estimated values from the actual offer prices in the secondary real estate market in Kazan makes $9.14 \%$, in absolute expression 5.83 thous. rub/sq. m. (Table 2).

TABLE II. ESTIMATE OF THE AVERAGE MONTHLY PRICES IN THE SECONDARY REAL ESTATE MARKET IN KAZAN UNDER THE EQUATION (4) AND DEVIATIONS FROM ACTUAL VALUES

\begin{tabular}{|c|c|c|c|c|}
\hline Month & $\begin{array}{l}\text { Average } \\
\text { monthly } \\
\text { unit price } \\
\text { in the } \\
\text { secondary } \\
\text { real estate } \\
\text { market in } \\
\text { Kazan, } \\
\text { thous.rub/s } \\
\text { qm. (actual } \\
\text { values) }\end{array}$ & $\begin{array}{l}\text { Average } \\
\text { monthly unit } \\
\text { price in the } \\
\text { secondary } \\
\text { real estate } \\
\text { market in } \\
\text { Kazan, } \\
\text { thous.rub/sq } \\
\text { m. (estimated } \\
\text { values) }\end{array}$ & $\begin{array}{l}\text { Deviations } \\
\text {, absolute } \\
\text { values, } \\
\text { thous.rub. }\end{array}$ & $\begin{array}{c}\text { Deviations, } \\
\% \text { of actual } \\
\text { value }\end{array}$ \\
\hline Aug.12 & 60.8 & 63.4 & 2.56 & 4.22 \\
\hline Sep.12 & 61 & 64.3 & 3.33 & 5.46 \\
\hline Oct. 12 & 61.7 & 65.2 & 3.52 & 5.71 \\
\hline Nov.12 & 61.9 & 66.0 & 4.13 & 6.68 \\
\hline Dec. 12 & 61.9 & 66.8 & 4.87 & 7.87 \\
\hline Jan. 13 & 63.3 & 67.4 & 4.13 & 6.53 \\
\hline Feb.13 & 63.2 & 68.0 & 4.83 & 7.64 \\
\hline Mar.13 & 62.1 & 68.6 & 6.46 & 10.40 \\
\hline Apr.13 & 62.2 & 69.0 & 6.82 & 10.97 \\
\hline May.13 & 61.9 & 69.4 & 7.54 & 12.18 \\
\hline Jun. 13 & 61.7 & 69.8 & 8.10 & 13.13 \\
\hline Jul.13 & 62.6 & 70.1 & 7.52 & 12.01 \\
\hline Aug.13 & 62 & 70.4 & 8.40 & 13.54 \\
\hline Sep.13 & 62.9 & 70.6 & 7.74 & 12.30 \\
\hline Oct.13 & 63.5 & 70.8 & 7.35 & 11.57 \\
\hline Nov.13 & 63.6 & 71.0 & 7.43 & 11.69 \\
\hline Dec.13 & 63.7 & 71.2 & 7.49 & 11.76 \\
\hline Jan.14 & 63.5 & 71.3 & 7.83 & 12.33 \\
\hline Feb.14 & 63.4 & 71.4 & 8.04 & 12.69 \\
\hline Mar.14 & 65.2 & 71.5 & 6.35 & 9.73 \\
\hline Apr.14 & 64.9 & 71.6 & 6.73 & 10.38 \\
\hline May .14 & 66.6 & 71.7 & 5.11 & 7.67 \\
\hline Jun.14 & 67.5 & 71.8 & 4.28 & 6.33 \\
\hline Jul.14 & 67.4 & 71.8 & 4.43 & 6.58 \\
\hline Aug.14 & 67.9 & 71.9 & 3.98 & 5.86 \\
\hline Sep.14 & 68.1 & 71.9 & 3.82 & 5.61 \\
\hline Oct. 14 & 67 & 72.0 & 4.96 & 7.40 \\
\hline Nov.14 & 66.2 & 72.0 & 5.79 & 8.74 \\
\hline Dec. 14 & 66.6 & 72.0 & 5.41 & 8.13 \\
\hline \multicolumn{3}{|c|}{ Average deviation index: } & 5.83 & 9.14 \\
\hline \multicolumn{3}{|c|}{ Maximum deviation: } & 2.56 & 4.22 \\
\hline \multicolumn{3}{|c|}{ Minimum deviation: } & 8.40 & 13.54 \\
\hline
\end{tabular}

By analyzing the offer prices in the real estate market in the period from 2014 till 2017, one can note a significant influence of devaluation of rouble to the price of $1 \mathrm{sq}$. $\mathrm{m}$ of real estate at the end of 2014, the beginning of 2015 - under conditions of instability of the national currency rate many people invest cash in real property, as result of a hyper demand a rapid rise in real estate prices occurs (Fig. 3).

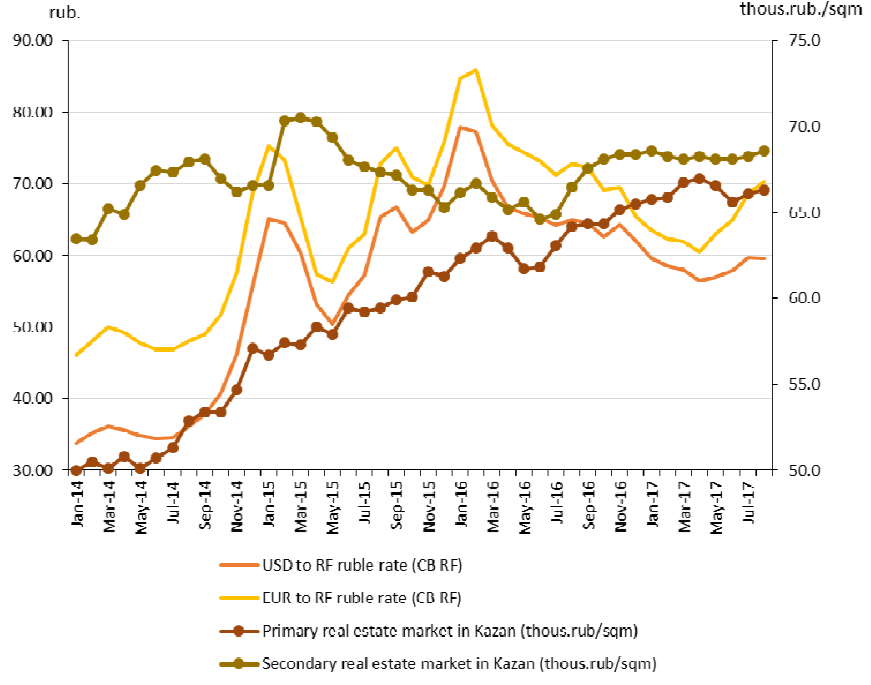

Fig. 3. Influence of the foreign currency market on real estate prices in Kazan

Meanwhile, difference in further price dynamics in the primary and the secondary real estate markets can be easily seen. For example, in the secondary real estate market after a rapid leap of the price of 1 sq. $m$, recession was seen (second half of 2015 and first half of 2016) with further recovery in the second half of 2016, which is well described by a polynomial of the third degree (Fig. 4).

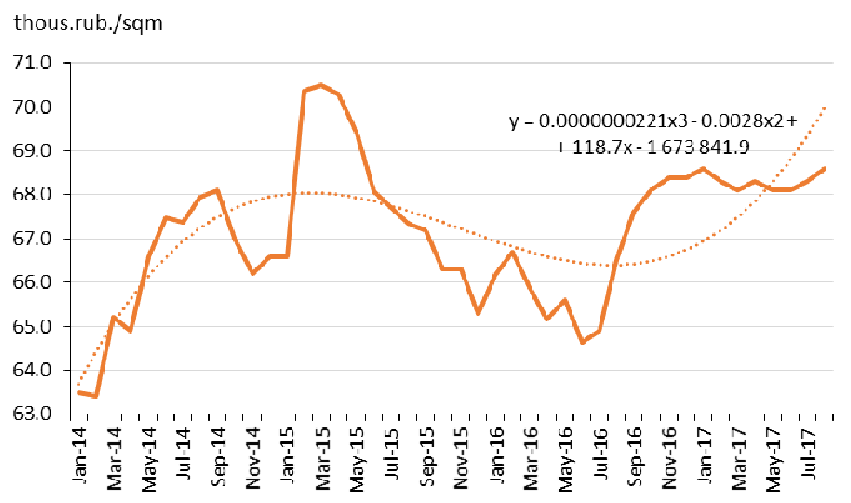

Fig. 4. The price dynamics in the secondary real estate market in Kazan for the period 2014-2017.

As opposed to the secondary real estate market, in the primary real estate market after a rapid rise of prices growth rates gradually wind down, while no recession or stagnation is seen (Fig. 5). The developed logistic model for this time interval appears as follows:

$$
Y_{3}=\frac{67.5}{1+e^{2.751109-0.13634 \cdot t}},
$$

where $Y_{3}$ is the average monthly offer price in the primary real estate market in Kazan, thous. rub/sq. m. 


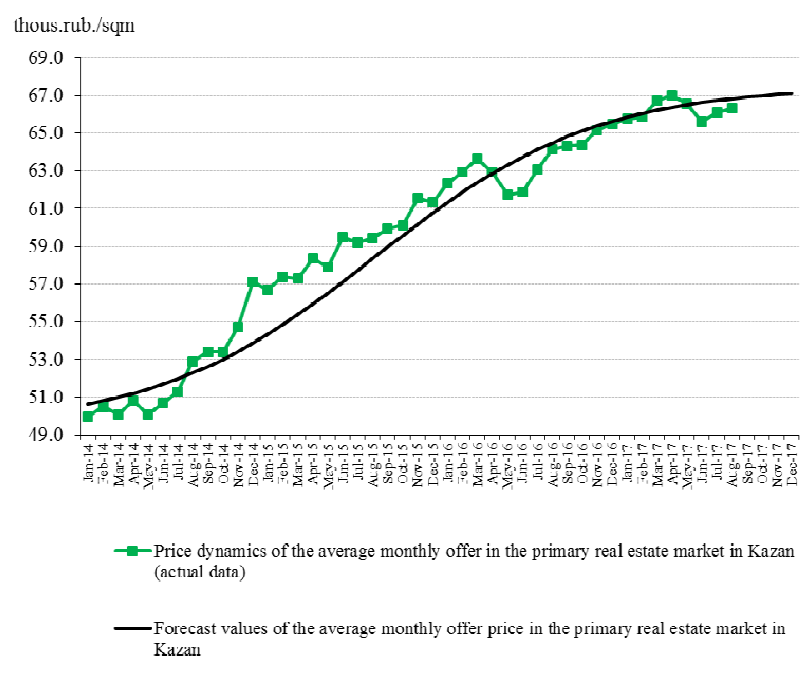

Fig. 5. The price dynamics in the primary real estate market in Kazan for the period 2014-2017 and forecast of price offer dynamics till the end of 2017.

Such difference in price offer dynamics in the researched markets of real estate can be mostly explained by measures taken for support of demand in certain areas of property market (e.g., subsidy programs for mortgage for purchase of property in the primary market), as well as by set of measures on the part of developers (for example, developed together with banking organizations programs of mortgage without a primary installment, decreased percent rate of mortgage, etc.).

Let us note the important preconditions that allow using logistic function to simulate the price dynamics in the real estate market in Kazan. First, under circumstances of the global financial crisis in September of 2009 in the primary and the secondary real estate markets in Kazan minimum level of prices was seen, starting from the beginning of 2007 (33.3 thous. rub/sq. m. in the primary real estate market and 36.8 thous. rub/sq. m. in the secondary real estate market). Since then, the real estate market began to gradually recover. Following the growing demand in real estate, price growing rates began to increase (Fig. 6).

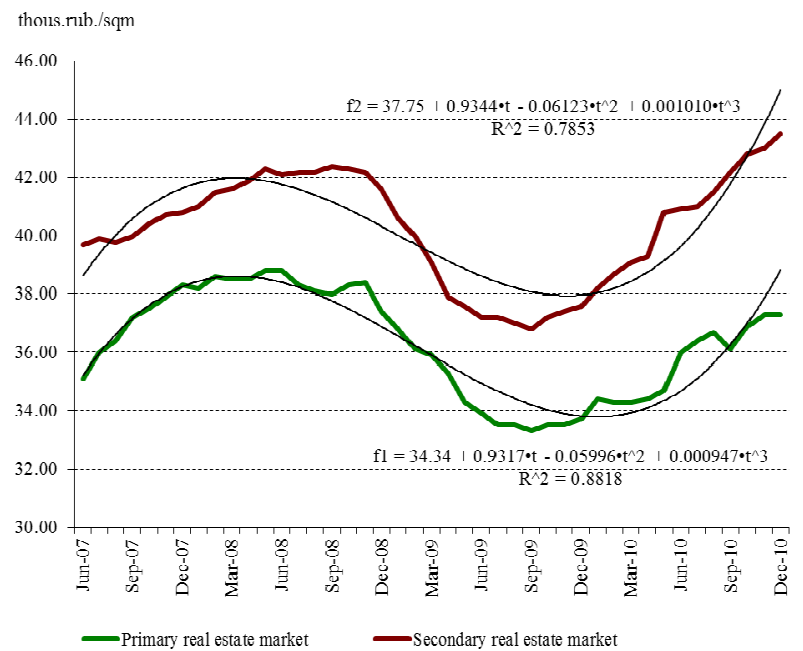

Fig. 6. Approximation of the price offer dynamics in the primary and the secondary real estate markets in Kazan in the period of the global financial crisis of 2008-09.
Secondly, in 2013 holding of the Summer Universiade in Kazan was planned, and starting from the mid2008, when Kazan was selected the capital of the Universiade2013, large-scale preparation work was performed, which included building new structures, sport objects, development of urban infrastructure (traffic routes, road junctions, modernization of transport, building reconstruction, etc.). Thus, during the period since 2009, 228 billion rubles were allocated for construction of sport and transport objects, as well as for service infrastructure. [16]. During preparation for the Universiade, 29 new sport objects and 11 junctions were built; 149 roads were reconstructed or built from anew with total length of $212 \mathrm{~km}$. Besides, in Kazan 13 parkings with capacity of 4800 cars, and 3 new metropolitan station were opened [16].

It is obvious that under such conditions the real estate market should develop with increased rate. This hypothesis was proved by the results of the comparative analysis of the price dynamics in the secondary real estate market in Kazan and a series of other major cities of the Privolzhsky federal region (Fig. 7).

The analysis results show that during two years (1 quarter of 2010- 1 quarter of 2012) price growing rates in the real estate market in Kazan significantly exceeded the similar index of the Privolzhsky federal region. However, starting from the $3^{\text {rd }}$ quarter of 2012, price-growing rates had greatly reduced, and in certain periods price fall was seen in the real estate market of Kazan (2 quarter of 2013, 4 quarter of 2014). Such a rapid change of trends negatively influenced the accuracy of the model developed by us (4).

Therefore, on the one hand, recovery from crisis and postcrisis market recovery, and, on the other hand, preparation for such large-scale event as the Universiade served as a background for application of the Fisher-Pry model to forecast the price dynamics in the real estate sector. Logistic functions quite accurately approximate the actual time series and simulate further development of processes that have S-shaped nature of development.

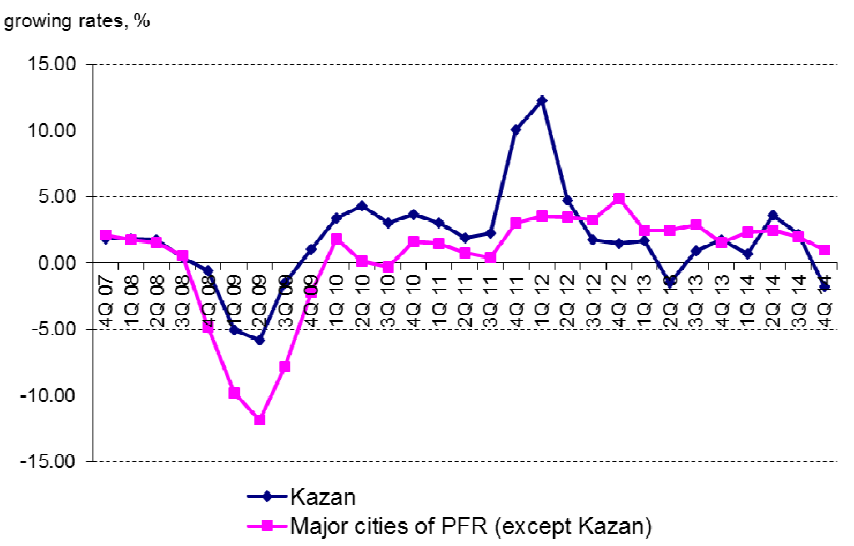

Fig. 7. Comparative analysis of the offer price dynamics in the secondary real estate market in Kazan and in certain major cities of the Privolzhsky federal region $(\mathrm{PFR})$

In future, situation in the real estate market in Kazan, just as in Russia as a whole, will be greatly dependent from the 
dynamics of social-economic development and resistance of the domestic economy against the external threats, which impact is rapidly growing under conditions of the sanction policy adopted by foreign states regarding Russia.

\section{References}

[1] I.S. Glebova, R. Khabibrakhmanova and Y. Yasnitskaya, "The Analysis of the Impact of the Investment Attractiveness Factors of the Region on the Fixed Capital Investments in the Economy of the Republic of Tatarstan”, Middle-East Journal of Scientific Research, 17 (10), pp. 1498-1502, 2013.

[2] I.R. Gafurov, N.G. Bagautdinova, M.V. Panasyuk, "Analysis of Strategic Perspectives of Competitiveness of Kazan", Recent Researches in Urban Sustainability, Architecture and Structures. Proceedings of the 2nd International Conference on Sustainable Cities, Urban Sustainability and Transportation (SCUST'13). Baltimore: WSEAS Press, pp. 37-44, September 17-19, 2013.

[3] A.S.a. Fotheringham, R.b. Crespo, J.c. Yao, "Exploring, modelling and predicting spatiotemporal variations in house prices", Annals of Regional Science, 4, 20 p, March 2015.

[4] B.a. Park, J.b Kwon Bae, "Using machine learning algorithms for housing price prediction: The case of Fairfax County, Virginia housing data", Expert Systems with Applications, Volume 42, Issue 6, 15, pp. 2928-2934, April 2015.

[5] Q. Feng, G.L Wu, Bubble or riddle? An asset-pricing approach evaluation on China's housing market", Economic Modelling, Volume 46, pp. 376-383, April 01, 2015.

[6] Y. Li, "The asymmetric house price dynamics: Evidence from the California market", Regional Science and Urban Economics Volume 52, pp. 1-12, May 01, 2015.

[7] W. Cai, X. Lu, "Housing affordability: Beyond the income and price terms, using China as a case study", Habitat International, Vol. 47, pp. $169-175,2015$.

[8] M.a, Wang, H.X.H. ${ }^{a}$ Bao, P.-T. ${ }^{b}$ Lin, "Behavioural insights into housing relocation decisions", The effects of the Beijing Olympics Habitat International, Volume 47, pp. 20-28, June 01, 2015.

[9] K.F. Ng, H.K. Lo, "Optimal housing supply in a bid-rent equilibrium framework", Transportation Research, Part B: Methodological, Volume 74, pp. 62-78, April 01, 2015.

[10] G.M. Sternik, S.G. Sternik, "Analysis of the real estate market for professionals". - M.: Publ. "Economy", 2009, 606 p.

[11] G.M. Sternik, S.G. Sternik, A.V. Sviridov, "Methods of forecasting of the Russian real estate market", Chapter 3. Evolution of methods of forecasting in the real estate market of Russia. Mechanization of construction, № 2, pp. 60-64, 2014.

[12] D. Kucharavy, and R. De Guio, "Logistic Substitution Model and Technological Forecasting", 8th ETRIA TRIZ Future Conference, University of Twente, Enschede, Netherlands, pp. 63-71, 2008.

[13] J. C. Fisher, R Pry, "A Simple Substitution Model for Technological Change", Technology Forecasting and Social Change, Vol.3, pp. 75-78, 1971.

[14] R. Steven Walk, "Quantitative Technology Forecasting Techniques, Technological Change”, Dr. Aurora Teixeira (Ed.), InTech, 2012.

[15] L.K. Vanston, R.L. Hodges, "Technology Forecasting for Telecommunications", Telektronikk, Vol.4.04, pp.32-42, 2004.

[16] What the Universiade , Newspaper "Vedomosti", № 3380 d.d. 05.07.2013. - $\quad$ Mode of access: http://www.vedomosti.ru/newspaper/articles/2013/07/05 